\title{
Studi Perilaku Kepatuhan Wajib Pajak dalam Membayar Pajak Daerah
}

\author{
Pramita Sukma. $\mathrm{W}^{\text {a }}$, Imam Subekti ${ }^{\text {a }}$, Rosidi ${ }^{\text {a }}$ \\ ${ }^{a}$ Universitas Brawijaya, Malang, Jawa Timur, Indonesia
}

INFORMASI ARTIKEL

\section{Article history:}

Dikirim tanggal: 17 Juli 2018

Revisi pertama tanggal: 23 Juli 2018

Diterima tanggal: 27 Agustus 2018

Tersedia online tanggal: 04 September 2018

Keywords: sikap atas kepatuhan pajak, kepercayaan atas pemerintah, niat untuk patuh, persepsi keadilan, kepatuhan membayar pajak daerah

\section{ABSTRACT}

The Objective of this research study is to examine the effect of attitude toward tax compliance on compliance pay local tax through the inttention to comply and to examine the effect of trust over government on compliance pay local tax through perception of justice. Data collected from questionnaire and analyzed with PLSbased SEM techniques with software SmartPLS version 2.0. The result of the analysis show both attitude toward tax compliance were found to be significantly on compliance pay local tax through the inttention to comply and the effect of trust over government also have a significant effect on compliance pay local tax through perception of justice.

\section{INTISARI}

Penelitian ini bertujuan untuk menguji pengaruh sikap atas kepatuhan pajak terhadap kepatuhan membayar pajak daerah melalui niat untuk patuh dan menguji pengaruh kepercayaan atas pemerintah terhadap kepatuhan membayar pajak daerah melalui persepsi keadilan. Data yang terkumpul dari kuesioner yang disebarkan kemudian dianalisis menggunakan model struktural berbasis PLS (Partial Least Square) dengan perangkat lunak SmartPLS versi 2.0. Hasil analisis ini menunjukan bahwa sikap atas kepatuhan pajak berpengaruh signifikan terhadap kepatuhan membayar pajak daerah melalui niat untuk patuh dan kepercayaan atas pemerintah juga berpengaruh signifikan terhadap kepatuhan membayar pajak daerah melalui persepsi keadilan.

2018 FIA UB. All rights reserved.

\section{Pendahuluan}

Kepatuhan pajak merupakan pemenuhan kewajiban perpajakan yang dilakukan oleh pembayar pajak dalam rangka memberikan kontribusi bagi pembangunan negara yang dilakukan secara sukarela (Rahayu, 2013). Namun kenyataannya, kewajiban perpajakan tersebut seringkali ditinggalkan yang akhirnya akan berdampak bagi penerimaan negara. Hal ini disebabkan kurangnya pemahaman masyarakat tentang pajak. Disisi lain, pajak akan menjadi sumber penerimaan negara yang menyumbang sekitar $70 \%$ dari seluruh peneriman negara. Tanpa pajak sebagian besar kegiatan negara akan sulit untuk dilaksanakan. Oleh sebab itu, perilaku kepatuhan wajib pajak dalam membayar pajak harus lebih ditingkatkan dengan tujuan memaksimalkan penerimaan negara dalam sektor pajak.

Di Indonesia sendiri terdapat dua jenis pelaksanaan pemungutan yaitu jenis pajak yang dipungut oleh

* Corresponding author. Tel.: +62-821-3153-6556; e-mail: pramita.sw@gmail.com 
pemerintah pusat dan jenis pajak yang dipungut oleh pemerintah daerah, yang biasanya disebut dengan pajak pusat dan daerah. Hampir seluruh wilayah yang ada di Indonesia akan lebih meningkatkan pertumbuhan ekonomi yang nantinya akan mendorong kemampuan masyarakat untuk membayar pajak daerah. Demikian juga Kabupaten Banyuwangi yang mengalami pertumbuhan perekonomian yang cukup signifikan, terlihat pada tabel 1 .

Tabel 1 PDRB Kabupaten Banyuwangi

Tahun 2011-2016

\begin{tabular}{|c|c|}
\hline Tahun & PDRB (Miliyar Rupiah) \\
\hline 2011 & $\operatorname{Rp} 27.060$ \\
\hline 2012 & $\operatorname{Rp~} 33.000$ \\
\hline 2013 & $\operatorname{Rp~35.460~}$ \\
\hline 2014 & $\operatorname{Rp} 53.408$ \\
\hline 2015 & $\operatorname{Rp} 60.218$ \\
\hline 2016 & $\operatorname{Rp} 63.952$ \\
\hline
\end{tabular}

Sumber: Rencana Kerja Pembangunan Daerah Kabupaten Banyuwangi Tahun 2017

Pencapaian PDRB (Produk Domestik Regional Bruto) tahun 2011 berhasil memperoleh sebesar Rp27.060 Miliyar. Pada tahun berikutnya, perolehan semakin meningkat sebanyak Rp33.000 Miliyar sehingga, pada tahun 2016 menjadi Rp63.952 Miliyar. Hal ini menunjukan bahwa kondisi perekonomian daerah Kabupaten Banyuwangi sudah sangat baik. Sektor yang menjadi penguat dalam PDRB adalah sektor pariwisata seperti perhotelan, restoran dan hiburan (RKPD Kabupaten Banyuwangi, 2017). Namun, disisi lain kenaikan Produk Domestik Regional Bruto Kabupaten Banyuwangi tidak diimbangi dengan adanya pemasukan Pendapatan Asli Daerah secara maksimal. Hal ini bisa dibuktikan bahwa pada tahun 2016 mengalami penurunan, terlihat pada Tabel 2.

Tabel 2 Pendapatan Asli Daerah Tahun 2011-2016

\begin{tabular}{|c|c|c|}
\hline Tahun & $\begin{array}{c}\text { Pendapatan Asli Daerah } \\
\text { (Miliar Rupiah) }\end{array}$ & Keterangan \\
\hline 2011 & Rp113,2 & Meningkat \\
\hline 2012 & Rp139,5 & Meningkat \\
\hline 2013 & Rp161,9 & Meningkat \\
\hline 2014 & Rp283,4 & Meningkat \\
\hline 2015 & Rp346,9 & Meningkat \\
\hline 2016 & Rp306,7 & Menurun \\
\hline
\end{tabular}

Sumber: Hasil analisis, 2018

Tabel 2 menunjukan adanya penurunan Pendapatan Asli Daerah Kabupaten Banyuwangi pada Tahun 2016. Hal ini mengindikasikan adanya ketimpangan peningkatan Produk Domestik Regional Bruto disetiap tahun, tapi tidak diimbangi dengan adanya peningkatan pemasukan pajak yang maksimal khusus pada Tahun 2016. Hal ini menunjukan, bahwa adanya ketidakpatuhan wajib pajak dalam melaksanakan aktivitas membayar pajak.

Kesadaran untuk membayar pajak tidak tumbuh secara langsung dikehidupan masyarakat, karena masih kurangnya pemahaman masyarakat tentang pajak. Terbukti dengan adanya berita di Kabupaten Banyuwangi tentang puluhan pengusaha rumah makan dan restoran tidak mematuhi kewajiban dalam membayar pajak daerah (Bdy, 2016). Disisi lain, terdapat juga berita bahwa pelaku usaha tidak membayar pajak sesuai dengan pemasukan. Hal ini menunjukan kurangnya kesadaran jujur dalam jumlah material yang dilaporkan. Karena pembayar pajak cenderung asal-asalan dalam melakukan kewajiban perpajakan. Pelaku usaha tersebut khususnya perhotelan, rumah makan dan hiburan yang tidak membayar pajak sesuai dengan pemasukan (Fanani, 2017).

Fenomena inilah yang mendorong dilakukanya penelitian dan memahami persoalan yang terjadi terkait kepatuhan dalam membayar pajak hotel, restoran dan hiburan di Kabupaten Banyuwangi. Harapanya kepatuhan dapat meningkat yang akhirnya akan berdampak bagi penerimaan daerah khusus dari sektor pajak.

Penelitian terdahulu dibidang perpajakan (Damayanti et al., 2015a; Ernawati \& Purnomosidhi, 2011; Sulistianingtyas, 2016; Bobek \& Hatfield 2003), yang melakukan pengujian tentang perilaku wajib pajak kaitanya dengan kepatuhan pajak. Temuan empiris tersebut membuktikan bahwa kepatuhan pajak dapat meningkat apabila dipengaruhi oleh sikap atas kepatuhan pajak dan terdapat niat untuk patuh dalam melakukan sikap kepatuhan pajak tersebut. Disisi lain kepercayaan atas pemerintah juga menentukan tingkat kepatuhan wajib pajak (Scholz \& Lubell, 1998). Wajib pajak yang percaya dengan pemerintah menunjukan tingkat kepatuhan pajak yang lebih tinggi dibandingkan warga negara yang tidak percaya dengan pemerintah.

Berdasarkan beberapa uraian tersebut, maka penulis tertarik untuk melakukan penelitian mengenai keperilakuan kepatuhan wajib pajak hotel, restoran dan hiburan di Kabupaten Banyuwangi. Penelitian ini menggunakan variabel sikap atas kepatuhan pajak, kepercyaan atas pemerintah, niat untuk patuh dan persepsi keadilan dalam meningkatkan kepatuhan dalam membayar pajak daerah.

\section{Teori}

\subsection{Teori Perilaku Terencana}

Teori Perilaku Terencana (Theory of Planned Behavior) merupakan pengembangan lebih lanjut dari Teori Perilaku Beralasan (Theory of Reasoned Action). Asal teori ini adalah psikologi sosial yang dipergunakan 
untuk menjelaskan berbagai macam perilaku seseorang. Teori Perilaku Terencana ini memandang bahwa perilaku seseorang dipengaruhi oleh niat seseorang untuk melakukan atau tidak melakukan suatu perilaku. Hal ini dikarenakan niat dalam berperilaku merupakan motivasi yang akhirnya akan mempengaruhi perilaku seseorang (Ajzen, 1991).

Sikap sebagai kecenderungan psikologi yang diekspresikan dengan mengevaluasi suatu entitas dalam derajat suka atau tidak suka (Eagly \& Chaiken, 1993). Sikap juga ditentukan dengan adanya keyakinan mengenai konsekuensi yang nantinya akan diperoleh dari suatu perilaku individu (Ajzen, 2005). Keyakinan berkaitan dengan penilaian subjektif seseorang terhadap dunia disekitarnya, pemahaman individu mengenai diri sendiri dan lingkungannya, dilakukan dengan cara menghubungkan antara perilaku tertentu dengan berbagai manfaat atau kerugian yang mungkin diperoleh apabila individu melakukan atau tidak melakukannya. Melalui sikap, kita dapat memahami proses kesadaran yang menentukan individu lain ketika ia akan melakukan tindakan yang nyata (Wawan dan Dewi, 2011:20).

\subsection{Teori Psikologi Fiskal}

Teori Psikologi Fiskal pertama kali diperkenalkan oleh Schmolders (1959) yang menghubungkan antara ekonomi dan pendekatan perilaku, menekankan pada kurangnya motivasi bagi wajib pajak untuk membayar pajak karena tidak ada keuntungan yang nyata dari manfaat membayar pajak. Teori ini didasarkan pada paradigma manfaat yang menggambarkan suatu model dimana akan memperhitungkan biaya dan manfaat potensial yang diperoleh dari suatu tindakan yang nantinya akan dipilih (Devos, 2013). Teori Psikologi Fiskal juga bisa digunakan untuk menjelaskan persepsi wajib pajak terhadap pemerintah yang merupakan faktor terpenting dalam kepatuhan pajak (Damayanti, 2015). Turner (2005) mendeskripsikan bahwa tingkat kepatuhan pajak lebih dipengaruhi oleh kepercayaan wajib pajak terhadap pemerintah khusunya dalam sistem perpajakan. Dengan demikian, kepercayaan kepada pemerintah akan lebih menjadikan wajib pajak loyal terhadap kewajiban membayar pajak.

Teori Psikologi fiskal merupakan gabungan dari pendekatan ekonomi dan psikologi yang merupakan pilihan lain yang lebih baik untuk menjelaskan kepatuhan pajak (Hasseldine \& Bebbington, 1991). Disisi lain, teori ini juga melibatkan interaksi kontrak berupa pertukaran fiskal yang nantinya akan menunjukan hak dan kewajiban diantara kedua belah pihak, yaitu pembayar pajak dan pemerintah (Feld \& Frey, 2007). Pertukaran fiskal ini sangat penting untuk mencapai kepatuhan pajak bagi pembayar pajak. Karena jika pajak yang sudah dibayar dan pelayanan publik yang disediakan oleh pemerintah dianggap oleh wajib pajak merata, maka pembayar pajak mungkin cenderung untuk mematuhi peraturan perundang-undangan, namun bila wajib pajak menganggap pelayanan publik tidak merata, maka wajib pajak tidak akan mematuhi peraturan perundang-undangnya atau tidak adanya kepercayaan atas pemerintah (Rudolph, 2009).

\subsection{Pajak Daerah}

Menurut Undang-undang No 28 Tahun 2009 bahwa pajak daerah adalah kontribusi wajib pajak daerah yang terutang oleh orang pribadi atau badan yang bersifat memaksa berdasarkan undang undang, dengan tidak mendapatkan imbalan secara langsung dan digunakan untuk keperluan daerah bagi sebesar-besarnya kemakmuran rakyat. Dengan kata lain pajak daerah merupakan kontribusi peraturan pemerintah daerah yang hasilnya digunakan untuk membiayai pengeluaran daerah guna melaksanakan pembangunan, penyelenggaraan pemerintah daerah. Semakin besar pajak daerah maka semakin besar pula pendapatan asli daerah, dengan terealisasinya target dari pemerintah daerah atas pajak yang telah ditentukan maka akan memberikan indikasi yang baik bagi keuangan daerah dalam mengatur pembangunan dan pelayanan kepada masyarakat. Adapun yang termasuk dalam pajak daerah antara lain pajak hotel, pajak restoran, pajak hiburan, pajak air tanah, pajak penerangan jalan, pajak reklame, pajak mineral bukan logam, pajak sarang burung walet, pajak parkir, bea perolehan hak atas tanah dan bangunan, dan pajak bumi bangunan.

\subsection{Pengembangan Model dan Hipotesis}

Sumber Empiris Hubungan Antar Variabel dalam Model:

a) Bobek dan Hatfield (2003); Sulistianingtyas (2016); Damayanti (2015); Ernawati dan Purnomosidhi (2011); dan

b) Jimenez dan Iyer (2016), Holtz (2013) serta Zand (1972); Tongler (2007) Andreoni, Erard dan Feinstein (1998).

\section{Metode Penelitian}

Penelitian ini merupakan penelitian kuantitatif. Penelitian ini menekankan pada pengujian teori-teori melalui pengukuran variabel-variabel penelitian angka dan melakukan analisis data dengan prosedur statistik. Unit analisis dalam penelitian ini adalah pemimpin hotel, restoran dan hiburan atau seseorang yang merefleksikan usaha tersebut di Kabupaten Banyuwangi. Penelitian dilakukan dengan menguji secara empiris dan kuantitatif mengenai pengaruh sikap atas kepatuhan pajak terhadap kepatuhan membayar pajak daerah melalui niat untuk patuh dan pengaruh kepercayaan atas pemerintah 
terhadap kepatuhan membayar pajak daerah melalui persepsi keadilan.

Dalam penelitian ini, yang ditetapkan sebagai lokasi penelitian adalah Kabupaten Banyuwangi dengan target populasi hotel, restoran dan hiburan di Kabupaten Banyuwangi, dengan populasi sebanyak 230 dan sampel yang diambil secara acak sebanyak 145 sebagai responden penelitian. Teknik pengumpulan data menggunakan penyebaran kuesioner. Data yang terkumpul dianalisis dengan pendekatan persamaan model struktural berbasis Partial Least Square dengan bantuan aplikasi software SmartPLS 2.0.

\section{Hasil Penelitian dan Pembahasan}

\subsection{Hasil Analisis Partial Least Square}

Pada masing-masing variabel yang diamati dalam penelitian dapat dilihat, antara lain sebagai berikut:

a) Variabel sikap atas kepatuhan pajak $\left(\mathrm{X}_{1}\right)$, indikator dengan bobot faktor tertinggi adalah indikator tentang "perasaan diuntungkan dengan sistem perpajakan" $\left(\mathrm{X}_{1.3}\right)$ dengan koefisien outer loading sebesar 0,886 dan $t$-statistics sebesar 39,279. Sementara indikator terendah adalah "keinginan membayar pajak dengan benar" $\left(\mathrm{X}_{1.1}\right)$ dengan koefisien outer loading sebesar 0,752 dan $t$-statistics sebesar 14,858;

b) Variabel kepercayaan atas pemerintah $\left(\mathrm{X}_{2}\right)$, indikator dengan bobot faktor tertinggi adalah indikator tentang "perkembangan ekonomi" $\left(\mathrm{X}_{2.2}\right)$ dengan koefisien outer loading sebesar 0,905 dan t-statistics sebesar 42,823. Sementara indikator terendah adalah "distribusi pajak" $\left(\mathrm{X}_{2.3}\right)$ dengan koefisien outer loading sebesar 0,702 dan $t$-statistics sebesar 9,735;

c) Variabel niat untuk patuh $\left(\mathrm{Y}_{1}\right)$, indikator dengan bobot faktor tertinggi adalah indikator tentang "keputusan untuk patuh terhadap ketentuan perpajakan" $\left(\mathrm{Y}_{1.2}\right)$ dengan koefisien outer loading sebesar 0,935 dan t-statistics sebesar 42,277. Sementara indikator terendah adalah "keinginan akan konsistensi kepatuhan pajak" $\left(\mathrm{Y}_{1.3}\right)$ dengan koefisien outer loading sebesar 0,909 dan t-statistics sebesar 45,979;

d) Variabel persepsi keadilan $\left(\mathrm{Y}_{2}\right)$, indikator dengan bobot faktor tertinggi adalah indikator tentang "adil dalam perundang-undangan" $\left(\mathrm{Y}_{2.1}\right)$ dengan koefisien outer loading sebesar 0,829 dan t-statistics sebesar 22,929. Sementara indikator terendah adalah "Azas cetanitry" $\left(\mathrm{Y}_{2.6}\right)$ dengan koefisien outer loading sebesar 0,716 dan t-statistics sebesar 11,381; dan

e) Variabel kepatuhan membayar pajak $\left(\mathrm{Y}_{3}\right)$, indikator dengan bobot faktor tertinggi adalah indikator tentang "tepat pelaporan" $\left(\mathrm{Y}_{3.3}\right)$ dengan koefisien outer loading sebesar 0,955 dan t-statistics sebesar 48,732. Sementara indikator terendah adalah "tepat waktu sebelum jatuh tempo" $\left(\mathrm{Y}_{3.1}\right)$ dengan koefisien outer loading sebesar 0,874 dan t-statistics sebesar 34,918.

Tabel 3 Hasil Perhitungan Outer Model

\begin{tabular}{|c|c|c|c|c|c|}
\hline Konstruk & & Indikator & $\begin{array}{c}\text { Outer } \\
\text { Loading }\end{array}$ & $t$-Statistics & Ket \\
\hline \multirow{4}{*}{$\begin{array}{c}\text { Sikap atas } \\
\text { Kepatuhan } \\
\text { pajak } \\
\left(X_{1}\right)\end{array}$} & $X_{1,1}$ & $\begin{array}{l}\text { Keinginan } \\
\text { membayar pajak } \\
\text { dengan benar }\end{array}$ & 0,752 & 14,858 & Sign \\
\hline & $X_{1,2}$ & $\begin{array}{l}\text { Kontribusi } \\
\text { kepada negara }\end{array}$ & 0,809 & 21,428 & Sign \\
\hline & $X_{1.3}$ & $\begin{array}{l}\text { Perasaan } \\
\text { diuntungkan } \\
\text { dengan sistem } \\
\text { perpajakan }\end{array}$ & 0,886 & 39,279 & Sign \\
\hline & $X_{1.4}$ & $\begin{array}{l}\text { Perasaan } \\
\text { pemanfaatan } \\
\text { pajak yang } \\
\text { transparan } \\
\end{array}$ & 0,855 & 32,322 & Sign \\
\hline \multirow{4}{*}{$\begin{array}{l}\text { Kepercaya } \\
\text { an atas } \\
\text { Pemerintah } \\
\left(X_{2}\right)\end{array}$} & $X_{21}$ & $\begin{array}{l}\text { Persepsi tentang } \\
\text { sistem } \\
\text { perpajakan }\end{array}$ & 0,840 & 26,971 & Sign \\
\hline & $X_{2.2}$ & $\begin{array}{l}\text { Perkembangan } \\
\text { ekonomi }\end{array}$ & 0,905 & 42,823 & Sign \\
\hline & 42.2 & Distribusi pajak & 0,702 & 9,735 & Sign \\
\hline & $X_{24}$ & Manfaat pajak & 0,881 & 36,048 & Sign \\
\hline \multirow{3}{*}{$\begin{array}{l}\text { Niat untuk } \\
\text { Patuh } \\
\left(Y_{1}\right)\end{array}$} & $Y_{1,1}$ & $\begin{array}{l}\text { Kecenderunagn } \\
\text { patuh terhadap } \\
\text { ketentuan } \\
\text { perpajakan }\end{array}$ & 0,918 & 45,934 & Sign \\
\hline & $Y_{1,2}$ & $\begin{array}{l}\text { Keputusan } \\
\text { untuk patuh } \\
\text { terhadap } \\
\text { ketentuan } \\
\text { perpajakan }\end{array}$ & 0,933 & 47,277 & Sign \\
\hline & $Y_{1, a}$ & $\begin{array}{l}\text { Keinginan akan } \\
\text { konsistensi } \\
\text { kepatuhan pajak }\end{array}$ & 0,909 & 45,979 & Sign \\
\hline \multirow{7}{*}{$\begin{array}{l}\text { Persepsi } \\
\text { Keadilan } \\
\quad\left(Y_{2}\right)\end{array}$} & $Y_{21}$ & \multirow{2}{*}{$\begin{array}{l}\text { Adil dalam } \\
\text { perundang- } \\
\text { undangan. }\end{array}$} & 0,829 & 22,929 & Sign \\
\hline & $Y_{22}$ & & 0,777 & 18,487 & Sign \\
\hline & $Y_{2: \mathrm{a}}$ & \multirow{2}{*}{$\begin{array}{l}\text { Adil dalam } \\
\text { pelaksaan }\end{array}$} & 0,776 & 18,006 & Sign \\
\hline & $Y_{24}$ & & 0,777 & 16,962 & Sign \\
\hline & $Y_{25}$ & Asas equality & 0,812 & 15,393 & Sign \\
\hline & $Y_{26}$ & Asas certanitry & 0,716 & 11,381 & Sign \\
\hline & $Y_{2,7}$ & Asas convenience & 0,728 & 13,774 & Sign \\
\hline \multirow{3}{*}{$\begin{array}{c}\text { Kepatuhan } \\
\text { membayar } \\
\text { Pajak } \\
\text { Daerah } \\
\left(Y_{a}\right)\end{array}$} & $Y_{\mathrm{a}: 1}$ & $\begin{array}{l}\text { Tepat waktu } \\
\text { bahkan sebelum } \\
\text { jatuh tempo }\end{array}$ & 0,874 & 34,918 & Sign \\
\hline & $Y_{3.2}$ & Tepat jumlah & 0,896 & 43,672 & Sign \\
\hline & $Y_{2 \mathrm{a}}$ & Tepat pelaporan & 0,955 & 48,732 & Sign \\
\hline
\end{tabular}

Sumber: Hasil analisis, 2018

\subsection{Pengujian Hipotesis}

Signifikansi parameter yang diestimasi memberikan informasi yang sangat berguna mengenai hubungan antara variabel-variabel penelitian. Dasar yang digunakan dalam menguji hipotesis dalam penelitian ini adalah nilai yang terdapat pada output path coefficient. Kriteria yang diharapkan dalam pengujian hipotesis ini adalah ketika hipotesis ditolak atau nilai sig $<0,05$ (atau nilai $t$-statistics $>1,645$ ). 
Tabel 4 Pengujian Hipotesis

\begin{tabular}{|c|c|c|c|c|}
\hline $\begin{array}{c}\text { Hubungan antar } \\
\text { Konstruk }\end{array}$ & $\begin{array}{c}\text { - } \\
\text { statistics }\end{array}$ & Sig & $\begin{array}{l}\text { Cut- } \\
\text { off }\end{array}$ & Ket. \\
\hline $\begin{array}{l}\text { Sikap atas kepatuhan } \\
\text { pajak>Niat untuk } \\
\text { patuh>Kepatuhan } \\
\text { membayar pajak } \\
\text { daerah }\end{array}$ & 7,521 & 0,000 & 1,645 & Sign \\
\hline $\begin{array}{l}\text { Kepercayaan atas } \\
\text { pemerintah>Persepsi } \\
\text { keadilan>Kepatuhan } \\
\text { membayar pajak } \\
\text { daerah }\end{array}$ & 4,757 & 0,000 & 1,645 & Sign \\
\hline
\end{tabular}

Sumber: Hasil analisis, 2018

Sebagiamana tertera dalam tabel 4 untuk hasil uji $t$ statistics sudah melebihi 1,645 dan nilai signifkansinya lebih kecil dari 0,05. Secara keseluruhan hipotesis adalah signifikan. Maka selanjutnya dilakukan pembuktian hipotesis yakni sebagai berikut:

a) $H_{1}$ : Sikap atas kepatuhan pajak mempunyai pengaruh signifikan terhadap kepatuhan membayar pajak daerah melalui niat untuk patuh.

t-statistics antara sikap atas kepatuhan pajak terhadap kepatuhan membayar pajak daerah melalui niat untuk patuh berpengaruh positif sebesar 7,521 karena ditemukan lebih dari 1,645 dan nilai sig lebih kecil dari 0,05. Berdasarkan temuan tersebut maka hipotesis 1 dalam penelitian ini diterima. Hasil membuktikan bahwa terdapat pengaruh positif yang signifikan dari sikap atas kepatuhan pajak terhadap kepatuhan membayar pajak daerah melalui niat untuk patuh.

b) $\mathrm{H}_{2}$ : Kepercayaan atas pemerintah mempunyai pengaruh signifikan terhadap kepatuhan membayar pajak daerah melalui persepsi keadilan.

t-statistics antara kepercayaan atas keperintah terhadap kepatuhan membayar pajak daerah melalui persepsi keadilan berpengaruh positif sebesar 4,757 karena ditemukan lebih dari 1,645 dan nilai sig lebih kecil dari 0,05. Berdasarkan temuan tersebut maka hipotesis 2 dalam penelitian ini diterima. Hasil membuktikan bahwa terdapat pengaruh positif yang signifikan dari kepercayaan atas pemerintah terhadap kepatuhan membayar pajak daerah melalui persepsi keadilan.

\section{Kesimpulan}

Penelitin ini bertujuan untuk menguji efek secara tidak langsung melalui niat untuk patuh dan persepsi keadilan. Dari hasil analisis dan pembahasan maka dapat disimpulkan, antara lain sebagai berikut:

a) Sikap atas kepatuhan pajak mempunyai pengaruh signifikan terhadap kepatuhan membayar pajak melalui niat untuk patuh. Sesuai dengan uji hipotesis yang dilakukan telah mengungkap bahwa sikap atas kepatuhan pajak berdampak penting terhadap kepatuhan membayar pajak daerah jika melalui variabel niat untuk patuh. Semakin positif sikap wajib pajak hotel, restoran dan hiburan untuk patuh maka akan semakin kuat niat wajib pajak hotel, restoran dan hiburan untuk berperilaku patuh dalam membayar pajak daerah. Hasil temuan inii mengkonfirmasi penelitian sebelumnya seperti Bobek dan Hatfield, 2003; Sulistianingtyas, 2016; Damayanti, 2015; Ernawati dan Purnomosidhi, 2011, yang menyatakan bahwa sikap atas kepatuhan pajak berpengaruh positif terhadap kepatuhan membayar pajak melalui niat untuk patuh. Teori perilaku terencana yang dibangun oleh Ajzen (1991) juga memiliki pernyataan yang sama seperti penjelasan penelitian terdahulu bahwa sikap terhadap perilaku merupakan salah satu hal yang dapat mempengaruhi niat untuk berperilaku. Jika wajib pajak hotel, restoran dan hiburan merasakan bahwa kepatuhan membayar pajak daerah merupakan hal yang menguntungkan, maka wajib pajak tersebut akan bersikap positif dan mempunyai niat untuk patuh dalam melaksanakan kewajiban perpajakan; dan

b) Kepercayaan atas pemerintah mempunyai pengaruh signifikan terhadap kepatuhan membayar pajak melalui persepsi keadilan. Sesuai dengan uji hipotesis yang dilakukan telah mengungkap bahwa kepercayaan atas pemerintah berdampak penting terhadap kepatuhan membayar pajak daerah jika melalui variabel persepsi keadilan. Semakin positif kepercayaan wajib pajak hotel, restoran dan hiburan terhadap pemerintah maka akan semakin kuat perilaku untuk patuh dalam membayar pajak daerah melalui persepsi keadilan. Hasil temuan ini mendukung Teori Psikologi Fiskal yang dibangun oleh Schmölders (1959) yang memiliki pernyataan bahwa kepercayaan atas pemerintah merupakan penentu terciptanya kepatuhan membayar pajak. Dalam hasil penelitian hipotesis keenam ini memberikan analisis bahwa semakin tinggi kepercayaan atas pemerintah maka semakin tinggi juga kepatuhan membayar pajak daerah bila melalui persepsi keadilan. Wajib pajak harus merasakan adanya perlakuan adanya suatu perlakuan yang adil yang dilakukan oleh pemerintah. Perlakuan adil tersebut akan mengarahkan penilaian positif yang timbul dari dalam diri wajib pajak terhadap pemerintah.

\section{Daftar Pustaka}

Ajzen, I. (1991). The Theory of Planned Behavior. Organizational Behavior and Human Decision Processess, Vol. 50, pp. 179-211. 
Ajzen, I. (2005). Attitudes, Personality and Behavior, Second Edition. Berkshire, England: Open University Press.

Andreoni, J., Erard, B., \& Feinstein, J. (1998). Tax Compliace. Journal of Economic Literature, Vol. 36, No.2, pp. 818-860.

Bdy. (2016). Puluhan Pengusaha Rumah Makan di Banyuwangi Tak Patuhi Pajak Pendapatan Daerah. Dapat diakses pada: http://sidikkasusri.blogspot.com/2016/09/puluhan-pengusaharumah-makan-di.htm [Diakses 16 Januari 2018].

Bobek, D., \& Hatfield. (2003). An Investigation of the Theory of Planned Behavior and the Role of Moral Obligation in Tax Compliance. Behavioural Research In Accounting. Vol 15, No.1, pp. 13-38.

Damayanti, T. W. (2015). Analisis Kepatuhan Wajib Pajak: Tinjauan Berdasarkan teori Perilaku Terencana dan Teori Psikologi Fiskal dengan Orientasi Ketidakpastian dan Orientasi Religiusitas Sebagai Variabel Moderasi. Disertasi, Universitas Brawijaya, Malang.

Damayanti, T. W., Sutrisno, T., Subekti, I., \& Baridwan. Z. (2015a). Trust and Uncertainty Orientation: An Efforts to Create Tax Compliance in Social Psychology Framework. Procedia-Social and Behavioral Sciences, Vol. 211(September), pp. 938-944.

Devos, K. (2013). Factor Influencing Individual Taxpayer Compliance Behavior. Springer, Netherland.

Eagly, A. H., \& Chaiken, S. (1993). The Psychology of Attitudes. Fort Worth, TX: Harcourt Brace Jovanovitch.

Ernawati, W.D., \& Purnomosidhi, B. (2011). Pengaruh Sikap, Norma Subyektif, Kontrol, Perilaku yang Dipersepsikan dan Sunset Policy Terhadap Kepatuhan Wajib Pajak dengan Niat Sebagai Variabel Intervening. Dapat diakses pada: http://purnomo.lecture.ub.ac.id/files/2012/01/Peng aruh-sikap-dll-thd-kepatuhan-WP1.pdf [Diakses 16 Januari 2018].

Fanani, Ardian. (2017). Kantor KPP Banyuwangi akan Sandera Wajib Pajak Membandel. Detiknews [Internet], 13 Februari 2017. Dapat diakses pada: https://news.detik.com/berita-jawa-timur/d3421210/kantor-kpp-banyuwangi-akan-sanderawajib-pajak-membandel [Diakses 16 Januari 2018].

Feld, L. P., \& Frey, B. S. (2007). Tax Compliance as the Result of a Psychological Tax Contract: The Role of Incentives and Responsive Regulation. Law \& Policy, Vol. 29, No. 1, pp. 102-120.

Hasseldine, D., \& Bebbington, K. J. (1991). Blending Economic Deterrence and Fiscal Psychology
Models in the Design of Responses to Tax Evasion: The New Zealand Experience. Journal of Economic Psychology, Vol. 12, No. 2, pp. 299324.

Holtz, B. C. (2013). Trust Primacy: A Model of the Reciprocal Relations Between Trust and Perceived Justice. Journal of Management, Vol. 39, No. 7, pp. 1891-1923.

Jimenez, P., \& Iyer. G. S. (2016). Tax Compliance in a Social Setting: The Influence of Social Norms, Trust in Government, and Perceived Fairness on Taxpayer Compliance. Advances in Accounting, incorporating Advances in International Accounting, Vol. 34, pp. 17-26.

Pemerintahan Kabupaten Banyuwangi. (2017). Rencana Kerja Pembangunan Daerah Pemerintah Kabupaten Banyuwangi Tahun 2017. Banyuwangi: Pemerintah Kabupaten Banyuwangi.

Rahayu, Siti Kurnia. (2013). Perpajakan Indonesia, Konsep dan Formal. Graha Ilmu: Yogyakarta.

Rudolph, T. J. (2009). Political Trust, Ideology, and Public Support for Tax Cuts. Public Opinion Quarterly, Vol. 73, No. 1, pp. 144-158.

Sulistianingtyas, V. (2016). Studi Kepatuhan Wajib Pajak PBB P2 di Kota Probolinggo: Satu Perspektif Teori Keperilakuan Terencana dan Teori Atribusi. Tesis. Universitas Brawijaya, Malang.

Scholz, J. T., \& Lubell, M. (1998). Adaptive Political Attitude: Duty, Trust and Fear as Monitors of Tax Policy. American Journal of Political Science, Vol.42(3), pp. 903-920.

Schmölders, G. (1959). Fiscal Psychology: A New Branch of Public Finance. National Tax Association, Vol. 4, No. 4, pp. 340-345.

Turner, J. C. (2005). Explaining the Nature of Power: a Three-Process Theory. European Journal of Social Psychology, Vol. 35, No. 1, pp. 1-22.

Tongler, B. (2007). Tax Compliance and Tax Morale: A Theoretical and Empirical Analysis. Northampton, MA: Edward Elgar Publishing, Inc.

Undang-undang Nomor 28 Tahun 2009 tentang Pajak Daerah dan Retribusi Daerah.

Wawan, A., \& Dewi, M. (2011). Teori dan Pengukuran Pengetahuan, Sikap dan Perilaku Manusia cetakan kedua. Nuha Medika: Yogyakarta.

Zand, D. E. (1972). Trust and Managerial Problem Solving. Administrative Science Quarterly, Vol.17, No. 2, pp. 229-239. 